\title{
Nutritional status of yellow passion fruit submitted to nitrogen sources by fertigation
}

Regiana dos Santos Moura ${ }^{*}$, Adenaelson de Sousa Marques², Elton Jonh Santos Silva ${ }^{3}$,

Gabriel Barbosa da Silva Junior ${ }^{4}$, Tiago Medeiros de Sousa ${ }^{3}$, Everaldo Moreira da Silva ${ }^{3}$

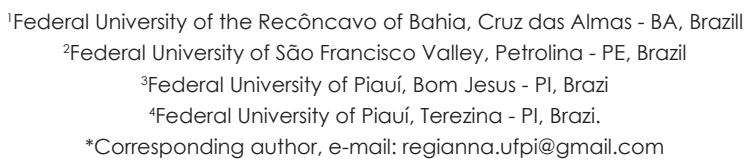

\begin{abstract}
Yellow passion fruit is the most cultivated species in Brazil and requires high amounts of nitrogen and an adequate nutritional status to express its entire productive potential. In this sense, this study aimed to evaluate the effect of different sources and doses of nitrogen via fertigation on nutritional status and leaf chlorophyll of yellow passion fruit. The experiment was conducted from June 2013 to August 2014 in Gurgueia Valley, Cristino Castro county, Piaui State, Brazil. The experimental design was randomized blocks with four replications, in a $2 \times 5$ factorial design related to the application of two nitrogen sources (urea and ammonium sulfate) and five $\mathrm{N}$ levels $\left(100,200,300,400\right.$ and $500 \mathrm{~kg} \mathrm{ha}^{-1}$ year-1). Six plants per replication were considered, totaling 240 plants, spaced $3 \mathrm{~m}$ between rows and $3 \mathrm{~m}$ between plants, and covering an area of 2,160 $\mathrm{m}^{2}$. At pre-flourishing, it was evaluated leaf chlorophyll index and leaf nitrogen, phosphorus, potassium, calcium, magnesium and sulfur contents. Urea increases $\mathrm{Ca}$ and $\mathrm{Mg}$ leaf contents and reduces leaf $S$ content in relation to ammonium sulfate. The increase in nitrogen fertilizing levels enhances leaf $\mathrm{N}$ and $\mathrm{Mg}$ concentrations. For $\mathrm{Ca}$, the optimal ammonium sulfate dose is $296.30 \mathrm{~kg} \mathrm{ha}^{-1}$.
\end{abstract}

Keywords: nitrogen fertilization, plant nutrition, macronutrients, Passiflora edulis

\section{Introduction}

The economic exploitation of yellow passion fruit (Passiflora edulis Sims f. Flovicarpa Deg) began in the 1970s, and it is still expanding in Brazil, which is the largest global producer and consumer of this fruit. This species represents approximately $95 \%$ of the national production of passion fruit. Only in 2013, Brazil produced approximately 776.000 t of passion fruit (Agrianual, 2014). The Northeast region is the largest producer, accounting for $73 \%$ of the national production, especially in Bahia state, which leads the ranking of area harvested, with 29.938 hectares and producing 320.945 t.

Passion fruit plants need a high amount of nitrogen in its structure. It is the most required nutrient for the fruiting period, making it necessary to complement nutrition with other nutrients, as it has alternate fluxes of vegetation and production (Rebequi et al., 2011). For a greater economic exploitation of this crop, there is a need to develop technologies that contribute to increase fruit yield, especially for fertigation and nutrient management areas. Therefore, the knowledge on nutritional status is a basic requirement for a proper mineral nutrition, essential to achieve a high fruit yield.

The use of chemical plant analyses to evaluate the nutritional status is based on the assumption that there is a causal relation 
between growth rate or production rate and nutrient content in dry or fresh matter, or nutrient concentration, in the solution of the plant tissue (Marschner, 2005).

However, studies studying the nutritional status of passion fruit as a function of nitrogen fertilization by fertigation are scarce in the scientific literature. Similarly, studies on the main sources of $\mathrm{N}$ applied by fertigation for fruit cultivation still require further scientific relevance. Thus, there is a need for further research on nutrition of passion fruit. There from emerge some hypotheses to be tested: (a) nitrogen fertilization with balanced amounts of $\mathrm{N}$ increases the absorption of this element and its use efficiency, reflecting on nutritional quality of plants; (b) different sources of $\mathrm{N}$ applied via fertigation influence leaf macronutrient contents of passion fruit.

Thus, this study aimed to evaluate the effect of different sources and doses of nitrogen via fertigation on nutritional status and leaf chlorophyll of yellow passionfruit in Gurgueia Valley, Piaui State, Brazil.

\section{Material and Methods}

Location of the experimental area

The experiment was developed in Cristino Castro county, southern Piauí state (0840'55.39" S, 4405'09.42" W, altitude $240 \mathrm{~m}$ ), in the Gurgueia River valley from June 2013 to August 2014. This region has a hot and humid climate, classified by Köppen as Cwa, with an average rainfall between 900 and $1.200 \mathrm{~mm}_{\text {year }}{ }^{-1}$ distributed from October to April, and an average annual temperature of $26.6^{\circ} \mathrm{C}$.

\section{Seeds and seedling production}

Yellow passion fruit seeds of IAC 273 cultivar were used. To produce seedlings, the seeds were sown at a depth of approximately 1.0 $\mathrm{cm}$ in polypropylene bags $(10 \times 20 \mathrm{~cm})$ filled with substrate composed by dried cattle manure, washed sand and plant substrate (2:1:1). Manual irrigation was performed twice daily according to the plant water requirement.

The transplanting was made when seedlings showed the first tendrils, at $30-40 \mathrm{~cm}$ height, approximately at 45 days after sowing.

Treatments and experimental design

The experimental design used was randomized blocks with four replications, in a 2 x 5 factorial design related to the application of two nitrogen sources (urea and ammonium sulfate) and $5 \mathrm{~N}$ doses (100, 200, 300, 400 and

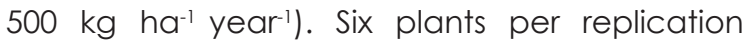
were considered, totaling 240 plants, spaced 3 $\mathrm{m}$ between rows and $3 \mathrm{~m}$ between plants, and covering an area of $2.160 \mathrm{~m}^{2}$. The $\mathrm{N}$ doses were $33,67,100,133$ and $167 \%$ of the optimal dose (300 kg ha year $^{-1}$ ) recommended for passion fruit plants (Embrapa, 2002).

Table 1. Chemical and physical characteristics of the soil before the experiment in the layers 0-20 and $20-40 \mathrm{~cm}$

\begin{tabular}{|c|c|c|c|c|c|c|c|}
\hline \multirow{2}{*}{$\begin{array}{l}\text { Chemical } \\
\text { Attributes } \\
\text { Depth }\end{array}$} & \multirow{2}{*}{$\begin{array}{l}\text { Unit } \\
\mathrm{Cm}\end{array}$} & \multicolumn{2}{|c|}{ Value } & \multirow{2}{*}{$\begin{array}{l}\text { Physical Attributes } \\
\text { Depth }\end{array}$} & \multirow{2}{*}{$\begin{array}{l}\text { Unit } \\
\mathrm{cm}\end{array}$} & \multicolumn{2}{|c|}{ Value } \\
\hline & & $0-20$ & $20-40$ & & & $0-20$ & $20-40$ \\
\hline $\mathrm{pH}$ & $\mathrm{CaCl}$ & 5.10 & 4.80 & OM & $\mathrm{g} \mathrm{kg}^{-1}$ & 11.00 & 12.00 \\
\hline B & $\mathrm{mg} \mathrm{dm}^{-3}$ & 0.19 & 0.23 & Sand & $\mathrm{g} \mathrm{kg}^{-1}$ & 840.00 & 86.00 \\
\hline $\mathrm{Zn}$ & $\mathrm{mg} \mathrm{dm}^{-3}$ & 2.20 & 2.40 & Silt & $\mathrm{g} \mathrm{kg}^{-1}$ & 50.00 & 40.00 \\
\hline$P$ & $\mathrm{mg} \mathrm{dm}^{-3}$ & 10.80 & 37.40 & Clay & $\mathrm{g} \mathrm{kg}^{-1}$ & 110.00 & 100.00 \\
\hline $\mathrm{K}^{+}$ & $\mathrm{mg} \mathrm{dm}^{-3}$ & 59.00 & 72.00 & SD & $\mathrm{kg} \mathrm{dm}^{-3}$ & 1.40 & 1.60 \\
\hline $\mathrm{H}+\mathrm{Al}^{3+}$ & $\mathrm{cmolc} \mathrm{dm}^{-3}$ & 1.60 & 1.60 & $\mathrm{PD}$ & $\mathrm{kg} \mathrm{dm} \mathrm{m}^{-3}$ & 2.60 & 2.60 \\
\hline $\mathrm{Al}^{3+}$ & $\mathrm{cmolc} \mathrm{dm}^{-3}$ & 0.00 & 1.00 & Total porosity & $\%$ & 38.60 & 46.10 \\
\hline $\mathrm{Ca}^{2+}$ & $\mathrm{cmolc} \mathrm{dm}^{-3}$ & 1.30 & 1.00 & Classification & & \multicolumn{2}{|c|}{ Sandy loam } \\
\hline $\mathrm{Mg}^{2+}$ & $\mathrm{cmolc} \mathrm{dm}^{-3}$ & 0.30 & 0.30 & FC & $\mathrm{cm}^{3} \mathrm{~cm}^{-3}$ & 0.17 & 0.19 \\
\hline BS & $\mathrm{cmolc} \mathrm{dm}^{-3}$ & 1.75 & 1.48 & PWP & $\mathrm{cm}^{3} \mathrm{~cm}^{-3}$ & 0.11 & 0.14 \\
\hline CEC & $\%$ & 3.35 & 3.08 & & & & \\
\hline V & $\%$ & 52.24 & 48.05 & & & & \\
\hline$M$ & $\%$ & 0.00 & 6.30 & & & & \\
\hline
\end{tabular}

P, K: Extractors: Melich ( $\left.\mathrm{HCl}+\mathrm{H}_{2} \mathrm{SO}_{4}\right)$; $\mathrm{Al}, \mathrm{Ca}, \mathrm{Mg}$ : Puller $\mathrm{KCl} \mathrm{M}$; OM = organic matter; $\mathrm{BS}=$ base sum; $\mathrm{V}=$ base saturation; $\mathrm{CEC}=$ cation exchange capácity; $\mathrm{SD}=$ Soil density, $\mathrm{PD}=$ particle density, $\mathrm{FC}=$ Field capacity $(-10 \mathrm{kPa})$ and $\mathrm{PWP}=$ Permanent Wilting Point $(-1,500 \mathrm{kPa})$. 
Characterization of the experimental area and experiment conduction

The chemical and physical characteristics of the soil of the experimental area are shown in Table 1. Data on climatic variables (air temperature, relative humidity and precipitation) collected at the weather station of the CPCE/ UFPI during the execution of the experiment, are shown in Figure 1.

Soil preparation consisted of plowing and then harrowing. At this moment, soil correction was made by incorporating dolomitic limestone with a full neutralization relative power of $80 \%$ at 60 days before transplanting using a disc harrow attached to a tractor. The liming demand was determined by the $\mathrm{Al}^{3+}$ neutralization method and by the increase of $\mathrm{Ca}^{2+}+\mathrm{Mg}^{2+}$ aiming to increase base saturation to $80 \%$, corresponding to 2.58 † $\mathrm{ha}^{-1}$. The liming calculation demand was made with the averages of soil chemical characteristics in the two sampling depths (0-20 and $20-40 \mathrm{~cm}$ ) (Table 1).

For the guiding of plants, a vertical support system was installed using wooden stacks at $1.8 \mathrm{~m}$ height, spaced $3 \times 3 \mathrm{~m}$, with a flat wire $\mathrm{n}^{\circ} 12$ tensioned at the top of the stacks in each cultivation row.

The holes were opened with $40 \times 30 \times 30$ $\mathrm{cm}$ dimensions in a rectangular system with 12 liters of cattle manure.
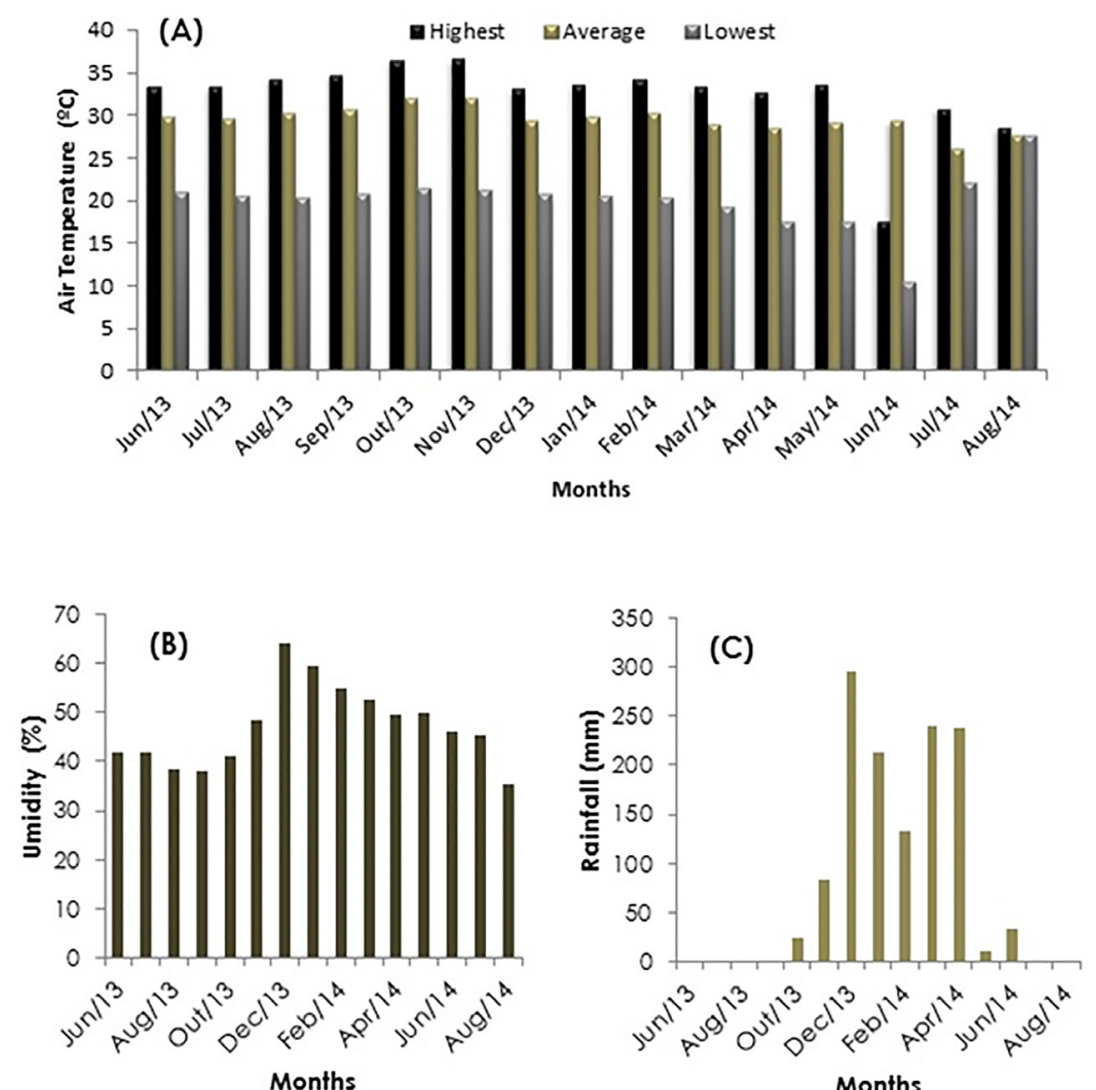

Figure 1. Monthly air temperature (A), relative humidity (B) and rainfall (C) during the execution of the experiment.

A drip irrigation was adopted using autocompensating emitters coupled to polyethylene lines $16 \mathrm{~mm}$ in diameter, with a nominal flow rate of $4 \mathrm{~L} \mathrm{~h}^{-1}$, which were previously evaluated under normal operating conditions. Water uniformity distribution (CUD) was verified at $98.4 \%$, considered optimal for this purpose (Araquam et al., 2012). A water blade equivalent to the daily corrected evapotranspiration was daily provided according to the passion fruit crop coefficient (Kc) reported by FAO 56. Soil moisture was indirectly verified with a tensiometer, correlating with the soil water retention curve (Figure 2).

The irrigation system consisted of 240 transmitters, with one emitter per plant. Irrigation management was made based on data obtained indirectly with the tensiometer installed $15 \mathrm{~cm}$ away from the base of the plants at 20 


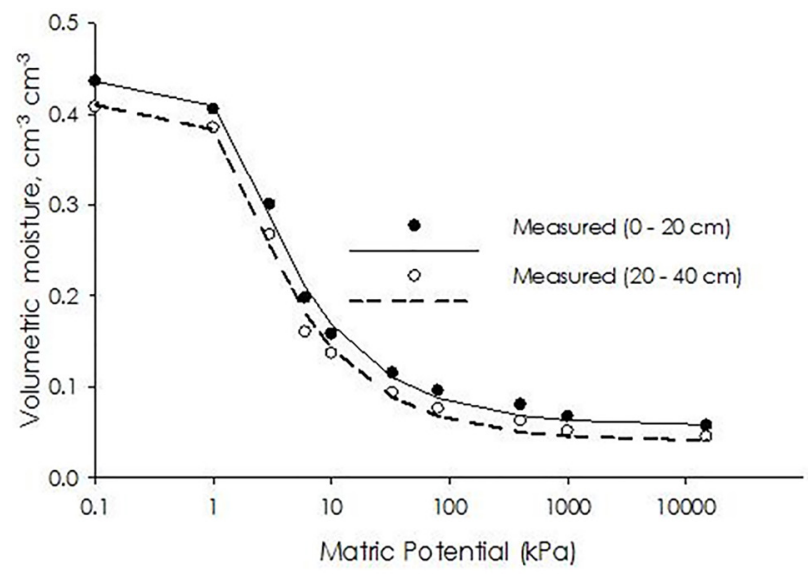

Figure 2. Soil water retention curve in the depths $0-20$ and $20-40 \mathrm{~cm}$.

and $40 \mathrm{~cm}$ soil depths. Tensiometer readings were performed daily around 08:00 a.m., considering an exploited layer of $40 \mathrm{~cm}$. The irrigation was made when the water pressure in the soil reached a critical moisture point according to the soil water retention curve. The water source (water $\mathrm{pH}=5.95$ ) used in the experiment flowed through a tube well near the experimental area. A disc filter was placed at the head control.

The $\mathrm{N}, \mathrm{K}_{2} \mathrm{O}$ and $\mathrm{S}$ fertilizations were applied by fertigation. The nutrient sources used were urea, potassium chloride and ammonium sulfate, respectively. The first fertigation was performed at 15 days after transplanting, in a week interval sequence, throughout the crop cycle, as recommended by Embrapa (2002). It was distributed as follows: from total $\mathrm{N}$ and $\mathrm{K}$, $10 \%$ were applied in the first two months; $12 \%$ between the $3^{\text {rd }}$ and $4^{\text {th }}$ month; $15 \%$ between the $5^{\text {th }}$ and $6^{\text {th }}$ month; $19 \%$ between the $7^{\text {th }}$ and $8^{\text {th }}$ month; and $44 \%$ in the last 4 months. The fertilizer application was performed through a Venturi injector installed on the control head of the irrigation system. B and Zn micronutrients (Borax and zinc sulphate) were leaf sprayed twice during pre-flowering.

The formation and guiding pruning were made by eliminating all tendrils and lateral branches, leaving only the most vigorous branch, guiding it until $10 \mathrm{~cm}$ above the wire. At this stage, the terminal bud was eliminated, guiding the two secondary branches to each side of the espalier. Later, the apex of these branches were pruned to induce the growth of the tertiary or productive branches.
Variables studied and statistical analysis

The following evaluations were performed in plants: leaf chlorophyll index (LCI) readings in intermediate and healthy leaves in the pre-flowering, corresponding to 120 days after transplanting, using a Falker ${ }^{\circledR}$ chlorophyll meter. In each plot, two leaves were chosen. Three readings were performed on each leaf: at the base, in the middle part and at the apex.

To determine the plant nutritional status, i.e., the concentration of macronutrients, two leaves per plant were collected. The $3^{\text {rd }}$ or $4^{\text {th }}$ leaf of the mid branches were collected according to the methodology described by Malavolta etal. (1997), and the contents of $\mathrm{N}, \mathrm{P}, \mathrm{K}, \mathrm{Mg}, \mathrm{Ca}$ and $\mathrm{S}$ were determined according to Battaglia et al. (1983) methodology. The $\mathrm{N}$ was determined in solutions prepared from extracts obtained by sulfuric acid digestion using the semi-micro-Kjeldahl method; $\mathrm{P}$ and $\mathrm{S}$ were determined by spectrophotometry; $\mathrm{K}, \mathrm{Ca}$ and $\mathrm{Mg}$ were determined by atomic absorption spectrophotometry.

The results were submitted to analysis of variance by $\mathrm{F}$ test, $\mathrm{N}$ sources were compared by Tukey test using the software Assistat 7.7. The $N$ levels were analyzed by polynomial regression using the software Sigmaplot 10.0, considering the highest degree equation and the highest coefficient of determination.

\section{Results and Discussion}

Individual effects of different nitrogen sources were observed for $\mathrm{Ca}(\mathrm{P}<0.05), \mathrm{Mg}$ and $S$ ( $p<0.01$ ) contents in passion fruit leaves. In relation to different $\mathrm{N}$ doses, there was significant effect for $\mathrm{N}$ and $\mathrm{Mg}(\mathrm{p}<0.01)$. The interaction 
between sources and $\mathrm{N}$ doses studied had $\mathrm{a}$ significant effect only on leaf $\mathrm{Ca}$ concentration at $1 \%$ probability.

The leaf chlorophyll index (LCF) was not affected by the nitrogen sources and doses studied (Table 2), similarly to the variation of leaf chlorophyll in yellow passion fruit studied by Silva Junior et al. (2013), who evaluated the nutritional status and leaf chlorophyll of yellow passion fruit as a function of biofertilizers, liming and fertilization with $\mathrm{N}$ and $\mathrm{K}$ in Bom Jesus, Piauí, Brazil and also found no significant effect on this photosynthetic pigment with soil nitrogen levels increasing.

Table 2. Summary of the variance analysis for leaf chlorophyll index (LCI), N, P, K, Ca, Mg and S concentrations in yellow passion fruit leaves as a function of different sources and doses of nitrogen applied via fertigation.

\begin{tabular}{|c|c|c|c|c|c|c|c|}
\hline Sources of $N(F)$ & $\mathrm{LCl}$ & $\mathrm{N}$ & $P$ & $\mathrm{~K}$ & $\mathrm{Ca}$ & $\mathrm{Mg}$ & $S$ \\
\hline Urea & 66.39 & 36.07 & 1.68 & 22.20 & 11.24 & 1.45 & 0.78 \\
\hline Ammonium sulfate & 67.07 & 36.85 & 1.63 & 23.47 & 9.97 & 1.30 & 1.24 \\
\hline MSD & 3.16 & 2.14 & 0.17 & 2.14 & 1.25 & 0.10 & 0.19 \\
\hline \multicolumn{8}{|l|}{$\mathrm{N}$ doses } \\
\hline $100 \mathrm{~kg} \mathrm{ha}^{-1}$ & 68.36 & 28.60 & 1.70 & 23.20 & 12.13 & 1.20 & 0.78 \\
\hline $200 \mathrm{~kg} \mathrm{ha}^{-1}$ & 66.57 & 34.15 & 1.53 & 23.33 & 11.18 & 1.25 & 1.10 \\
\hline $300 \mathrm{~kg} \mathrm{ha}^{-1}$ & 56.75 & 36.45 & 1.61 & 22.33 & 9.85 & 1.41 & 0.90 \\
\hline $400 \mathrm{~kg} \mathrm{ha}^{-1}$ & 67.23 & 41.16 & 1.66 & 22.55 & 10.43 & 1.48 & 1.13 \\
\hline \multirow[t]{2}{*}{$500 \mathrm{~kg} \mathrm{ha}^{-1}$} & 65.71 & 41.95 & 1.76 & 22.76 & 9.45 & 1.53 & 1.15 \\
\hline & & & & Value --- & (n) & (n) & --- \\
\hline $\mathrm{F}$ & $4.62^{\text {ns }}$ & $6.08^{\text {ns }}$ & $0.02^{\text {ns }}$ & $16.21^{\mathrm{ns}}$ & $16.21^{*}$ & $0.23^{* *}$ & $2.17^{* *}$ \\
\hline D & $9.81^{\mathrm{ns}}$ & $238.80^{* *}$ & $0.06^{\text {ns }}$ & $1.43^{\text {ns }}$ & $9.20^{\text {ns }}$ & $0.16^{* *}$ & $0.21^{\mathrm{ns}}$ \\
\hline$F \times D$ & $57.07^{\mathrm{ns}}$ & $2.57^{\mathrm{ns}}$ & $0.18^{\text {ns }}$ & $13.45^{\mathrm{ns}}$ & $23.50^{* *}$ & $0.06^{\text {ns }}$ & $0.11^{\mathrm{ns}}$ \\
\hline General average & 66.73 & 36.46 & 1.65 & 22.87 & 10.61 & 1.37 & 1.01 \\
\hline CV $(\%)$ & 7.34 & 9.05 & 15.82 & 14.44 & 18.15 & 11.98 & 28.44 \\
\hline
\end{tabular}

On the other hand, Freire et al. (2013), studying chlorophyll contents and leaf mineral composition of yellow passion fruit in Remígio, Paraiba state, Brasil, reported an increase in total leaf chlorophyll for plants grown with enriched biofertilizers and justified this result due to a higher nitrogen content of this fertilizer.

Probably the great divergence in such research results occurred because both were developed in field, where a great edaphoclimatic variability occurs, chlorophyll levels may not follow a tendency of values responsive to nitrogen sources and doses, even if this is the main nutrient responsible for the change of this pigment in leaves (Schlemmera et al., 2013). The function of chlorophyll is to absorb light incident on leaves for the photosynthesis process (Amarante et al., 2008). Jamil et al. (2007), Cavalcante et al. (2009) and Mendonça et al. (2010) observed that photosynthetic pigment levels in plants are reduced by the salinity of soil solution.

Leaf potassium ( $K$ ) had average values of 22.20 and 23.47 for urea and ammonium sulfate sources, respectively, and they were not influenced by the nitrogen sources and doses studied (Table 2). On the other hand, Rodrigues et al. (2009), evaluating the fruit production and nutrition of yellow passion fruit in soil with "supermagro" and potassium biofertilizers, observed that leaf potassium accumulation was stimulated by both "supermagro" values applied and potassium fertilizing, which is a situation different from the present study.

The sources of $\mathrm{N}$ affected calcium contents in leaves of yellow passion fruit (Table 2), with a superiority for $\mathrm{N}$ applied as urea, with an average value of $11.24 \mathrm{~g} \mathrm{~kg}^{-1}$, thus $11.29 \%$ higher than the average ammonium sulfate $\left(9.97 \mathrm{~g} \mathrm{~kg}^{-1}\right)$.

The Ca contents presented in this study (9.97-11.24 $\mathrm{g} \mathrm{plant}^{-1}$ ) are higher than the range 3.28-4.40 $\mathrm{g} \mathrm{kg}^{-1}$ reported by Silva Júnior et al. (2013) and Freire et al. (2013), with an average value of $7.00 \mathrm{~g} \mathrm{~kg}^{-1}$ of Ca. Santos et al. (2011), evaluated different sources of $\mathrm{N}$ and found that $\mathrm{Ca}$ in passion fruit plants fertilized with cattle manure plus ammonium sulfate was superior to other treatments, obtaining $16.27 \mathrm{~g} \mathrm{~kg}^{-1}$. Malavolta et al. (1997) consider that for a proper 
calcium nutrition, yellow passion fruit should present average Ca levels of $15-20 \mathrm{~g} \mathrm{~kg}^{-1}$.

Formagnesium, another nutrient affected by $\mathrm{N}$ sources, urea increased the $\mathrm{Mg}$ content in leaves, averaging $1.45 \mathrm{~g} \mathrm{~kg}^{-1}$, corresponding to a $10.35 \%$ superiority in relation to the $1.30 \mathrm{~g} \mathrm{~kg}^{-1}$ average promoted by ammonium sulfate (Table 2). Thus, it is observed that, like $\mathrm{Ca}, \mathrm{Mg}$ is also influenced by the $\mathrm{N}$ source applied to the soil due to chemical changes, especially the reduction of soil $\mathrm{pH}$, more intensified by ammonium sulfate, which alters the dynamics of cationic elements, thus reducing its absorption even by reducing the root system.

Whether compared the magnesium contents found in the present study with those recorded by other authors, it is possible to identify that the range $1.3-1.45 \mathrm{~g} \mathrm{~kg}^{-1}$ is inferior to the interval 2.62-3.08 $\mathrm{g} \mathrm{kg}^{-1}$ reported by Freire et al. (2013) and to the average of $1.5 \mathrm{~g} \mathrm{~kg}^{-1}$ registered by Silva Júnior et al. (2013). Moraes et al. (2011) presented results that were also superior to the range of leaf $\mathrm{Mg}$ presented in this study, with an average range $2.55-3.55 \mathrm{~g} \mathrm{~kg}^{-1}$. On the other hand, Malavolta et al. (1997) consider the Mg range 3-4 $\mathrm{g} \mathrm{kg}^{-1}$ as optimal for yellow passion fruit, therefore higher than the values found in this study.

The treatment with urea promoted lower sulfur levels (Table 2), with an average value of $0.78 \mathrm{~g} \mathrm{~kg}^{-1}$ in leaves. On the other hand, when plants were fertilized with ammonium sulfate, the average $S$ content was $1.24 \mathrm{~g} \mathrm{~kg}^{-1}$, evidencing a $37.09 \%$ difference between the amount of sulfur in leaves as a function of the $\mathrm{N}$ source applied via fertigation. According to Jamal et al. (2010), high nitrogen doses in the soil may reduce the availability of soil sulfur, thus affecting plants. The superiority of ammonium sulfate in relation to urea, for sulfur levels, is due to the presence of $24 \%$ of $\mathrm{S}$ in this nitrogen source $\left(\mathrm{NH}_{4}\right)_{2} \mathrm{SO}_{4}$, which favored a higher absorption of this element by passion fruit plants.

For the $\mathrm{N}$ doses studied, independently of the nitrogen source used, the leaf $\mathrm{N}$ concentrations were linearly increased with $\mathrm{N}$ doses enhancement via fertigation, with a maximum value of $42.9 \mathrm{~g} \mathrm{~kg}^{-1}$ of $\mathrm{N}$ for its highest dose $\left(500 \mathrm{~kg} \mathrm{ha}^{-1}\right)$, i.e., an increase of $31.27 \%$ when only $100 \mathrm{~kg} \mathrm{ha}^{-1}$ of $\mathrm{N}$ was applied (Figure 3a).

In a study about production, fruit quality and leaf nitrogen content of yellow passion fruit plants fertilized with nitrogen in Aquidauana, Mato Grosso do Sul state, Brazil, Venâncio et al. (2013) reported that leaf nitrogen was affected by different doses of nitrogen applied to the soil, fitting the linear regression model. The $\mathrm{N}$ doses increase enhanced leaf $\mathrm{N}$ contents, reaching $\mathrm{N}$ levels of $40.49 \mathrm{~g} \mathrm{~kg}^{-1}$ at the maximum dose applied to the soil (315 $\mathrm{g} \mathrm{plant}^{-1}$ of $\mathrm{N}$ ). In this study, a $42.9 \mathrm{~g} \mathrm{~kg}^{-1}$ of $\mathrm{N}$ was obtained for the maximum dose, with $450 \mathrm{~g} \mathrm{plant}^{-1}$ of $\mathrm{N}$. Similar results were also reported by Silva Júnior et al. (2013) for passion fruit crop.

Specifically for studies with nitrogen fertilizer via fertigation in passion fruit crop, there were few manuscripts in the scientific literature. Studies with other fruit crops such as papaya 'pawpaw' (Santos et al., 2014), vine (Brunetto et al., 2008), guava (Neto et al., 2013), in which the leaf $\mathrm{N}$ concentration increased with the increase
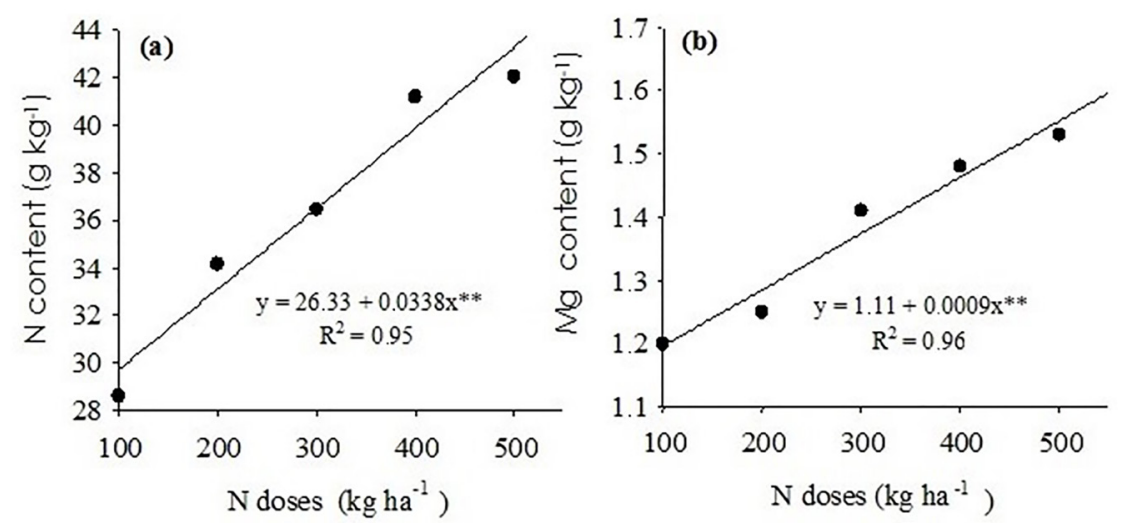

Figure 3. Leaf nitrogen (a) and magnesium (b) contents of yellow passion fruit cultivated with different doses of nitrogen. 
in $\mathrm{N}$ doses, may be cited, corroborating the results of this study.

Regarding leaf $\mathrm{Mg}$ (Figure $3 \mathrm{~b}$ ) and $\mathrm{N}$ contents, there was an increase in its values with the enhancement of $\mathrm{N}$ doses via fertigation, regardless of the $\mathrm{N}$ sources studied. The highest Mg leaf value was $1.56 \mathrm{~g} \mathrm{~kg}^{-1}$ for the $500 \mathrm{~kg} \mathrm{ha}^{-1} \mathrm{~N}$ dose, whilst, regarding the application of only 100 $\mathrm{kg} \mathrm{ha}^{-1}$, the $\mathrm{Mg}$ content was $1.20 \mathrm{~g} \mathrm{~kg}^{-1}$. Therefore, the increase of this nutrient was $23.07 \%$.

The Mg absorption rate may be affected by other cations such as $\mathrm{K}^{+}, \mathrm{NH}_{4}^{+}, \mathrm{Ca}^{2+}$ and $\mathrm{Mn}^{2+}$, as well as $\mathrm{H}^{+}$in low soil $\mathrm{pH}$ conditions (Heenan \& Campbell, 1981). Thus, the increase in leaf Mg with the highest dose of $\mathrm{N}$ may be related to the soil availability of $\mathrm{N}^{-\mathrm{NH}_{4}+}$. The functions of $\mathrm{Mg}$ in plants are mainly related to its ability to interact with nucleophilic ligands, such as phosphoric groups, through ionic bonds, acting as a bonding element or forming complexes with different stabilities. The $\mathrm{Mg}$ is part of the chlorophyll component, enzyme activation, and it affects $\mathrm{CO}_{2}$ assimilation, sugar synthesis, starch synthesis and ATP synthesis (P charger).

For leaf calcium contents (Figure 4), a quadratic regression response due to the decreasing application of $\mathrm{N}$ as ammonium sulfate is observed, with maximum values of $13.09 \mathrm{~g} \mathrm{~kg}^{-1}$ of calcium corresponding to a dose of $296.28 \mathrm{~kg}$ $\mathrm{ha}^{-1}$ of $\mathrm{N}$. As for the application of nitrogen as urea, there was a linear decrease in leaf calcium levels with the $\mathrm{N}$ fertilizer dose increase. The application of urea in the maximum dose 1500 $\mathrm{kg} \mathrm{ha}^{-1}$ ) reached a minimum value of $9.13 \mathrm{~g} \mathrm{~kg}^{-1}$, which corresponds to a $37.33 \%$ reduction in leaf calcium content.

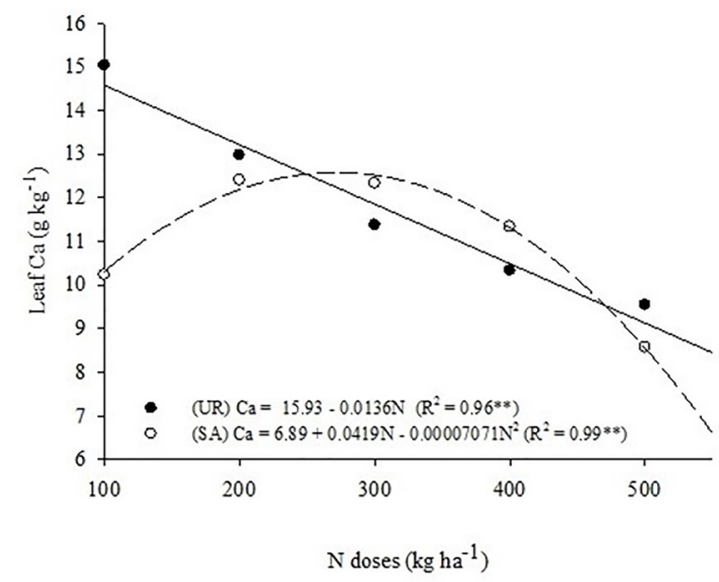

Figure 4. Leaf calcium content of yellow passion fruit cultivated under different doses of $\mathrm{N}$ as urea and ammonium sulfate.

In general, the increase of leaf calcium values with the application of $\mathrm{N}$ as ammonium sulfate occurred at lower $\mathrm{N}$ doses applied by fertigation $\left(296.38 \mathrm{~kg} \mathrm{ha}^{-1}\right)$. For urea, the highest leaf calcium value was observed for the lowest $\mathrm{N}$ dose applied, $100 \mathrm{~kg} \mathrm{ha}^{-1}$.

It is known that the change in the mineral composition of plants by nitrogen fertilization is directly related to the $\mathrm{N}$ form used or available in the soil. Thus, in this study, it was found that there was a strong leaf $\mathrm{Ca}$ reduction with $\mathrm{N}$ fertilizing increase independently of the $\mathrm{N}$ source used. This is justified by the acidifying power of both $\mathrm{N}$ sources, by the release of $\mathrm{H}^{+}$in the transformation of $\mathrm{NH}_{4}^{+}$into $\mathrm{NO}_{3}$; especially ammonium sulfate, which can be detrimental to plant growth because it affects availability and absorption of some nutrients, especially the cationic ones (Marschner, 2005) such as $\mathrm{Ca}^{2+}$ (Figure 4) and $\mathrm{Mg}^{+}$(Figure 3B), causing a nutritional imbalance. The calcium absorption inhibition reflected in lower leaf $\mathrm{Ca}$ contents due to the application of ammonium nitrogen fertilizers via fertigation in short periods, and it was also reported in research with different crops such as papaya (Santos et al., 2014).

\section{Conclusions}

Urea increases $\mathrm{Ca}$ and $\mathrm{Mg}$, and reduces leaf $S$ content in relation to ammonium sulfate.

The increase in nitrogen fertilizing levels enhances leaf $\mathrm{N}$ and $\mathrm{Mg}$ concentrations. For $\mathrm{Ca}$, the best ammonium sulfate dose is $296.30 \mathrm{~kg} \mathrm{ha}^{-1}$. 


\section{References}

AGRIANUAL. Anuário estatístico da agricultura brasileira. 2014. 19 Ed. São Paulo, FNP, 136 p.

Amarante, C.V.T., Bisognin, D.A., Steffens, C.A., Zanardi, O.Z., Alves, E.O. 2008. Quantificação não destrutiva de clorofilas em folhas através de método colorimétrico. Horticultura Brasileira 4: $471-475$

Araquam, W.W.C., Souza, L.F., Campeche, M. 2012. Avaliação da uniformidade de aplicação de água em sistemas de irrigação do perímetro irrigado Nilo Coelho em Petrolina-PE. Revista Semiárido de Visu 2: 303-316.

Bataglia, O.C., trani, P.E. 1983. Métodos de análise química de plantas. Instituto Agronômico, Campinas, Brasil. (Boletim Técnico 78).

Brunetto, G., Bongiorno, C.L., Mattias, J.L., Deon, M., Melo, G.W., Kaminski, J., Ceretta, C.A. 2008. Produção, composição da uva e teores de nitrogênio na folha e no pecíolo em videiras submetidas à adubação nitrogenada. Ciência Rural 38: 2622-2625.

Cavalcante, L.F., Silva, G.F., Gheyi, H.R., Dias, T.J., Alves, J.C., Costa, A.P.M. 2009. Crescimentode mudas de maracujazeiro amarelo em solo salino com esterco bovino líquido fermentado. Revista Brasileira de Ciências Agrárias 4: 414-420.

EMBRAPA. 2002. Empresa Brasileira de Pesquisa Agropecuária. (Embrapa Mandioca e Fruticultura) Maracujá Produção: Aspectos Técnicos. 1 Ed. Embrapa, Teresina, Brasil. 104 p.

Freire, J.L.O., Cavalcante, L.F., Nascimento, R., Rebequi, A.M. 2013. Teores de clorofila e composição mineral foliar do maracujazeiro irrigado com águas salinas e biofertilizante. Revista de Ciências Agrária. 36: 57-70.

Heenan, D.P., Campbell, L.C. 1981. Influence of potassium and manganese on growth and uptake of magnesium by soybeans (Glycine max L.) Merr. Cv Bragg. Plant Soil 61:447-456.

Jamal, A., Moon, Y., Abdin, M.Z. 2010. Sulphur - a general overview and interaction with nitrogen. Australian Journal of Crop Science4: 523-529.

Jamil, M., Rehman, S., Lee, K.J., Kim, J.M., Kim, H.S., Rha, E.S. 2007. Salinity reduced growth $P$ S2 photochemistry and chlorophyll content in radish. Scientia Agricola 64: 111-118.

Malavolta, E., Vitti, G.C.E., Oliveira, S.A. 1997. Avaliação do estado nutricional das plantas: princípios e aplicações. Associação Brasileira para Pesquisa da Potassa e do Fosfato, Piracicaba, Brazil. 319 p.

Marschner, H. 2005. Mineral nutrition of higher plants. 2 Ed. Academic Press, London,
UK. 889 p.

Mendonça, A.V.R., Carneiro, J.G.A., Freitas, T.A.S., Barroso, D.G. 2010. Características fisiológicas de mudas de Eucalyptus spp. submetidas a estresse salino. Ciência Florestal 20: 255-267.

Moraes, J.C.B., Salcedo, I.H., Sousa, V.F. 2011. Doses de potássio por gotejamento no estado nutricional do maracujazeiro. Revista Brasileira de Engenharia Agrícola e Ambiental 15: 763-770.

Neto, J.D., Maciel, J.L., Alves, A.S., Azevedo, C.A.V., Fernandes, P.D., Lima, V.L.A. 2013. Teores de macronutrientes em folhas de goiabeira fertirrigada com nitrogênio. Revista Brasileira de Engenharia Agrícola e Ambiental 17: 962-968.

Rebequi, A.M., Cavalcante, L.F., Diniz, A. A., Nunes, J.C., Brehm, M.A.S., Oliveira, F.A. 2011. Crescimento e produção de maracujazeiro amarelo sob diferentes níveis e combinações de adubações nitrogenada e potássica no solo e foliar nas plantas. Revista Magistra 23: 45-52.

Rodrigues, A.C., Cavalcante, L.F., Oliveira, A.P., Sousa, J.T., Mesquita, F.O. 2009. Produção e nutrição mineral do maracujazeiro-amareloem solo com biofertilizante supermagro e potássio. Revista Brasileira de Engenharia Agrícola e Ambiental 13: 117-124.

Santos, E.M., Cavalcante, Í.H.L., Silva Júnior, G.B., Albano, F.G., Lima, F.N., Sousa, A. M., Cavalcante, L.F. 2014. Estado nutricional do mamoeiro Formosa (cv. Caliman 01) em função de adubação com NK e espaçamento de plantio. Comunicata Scientiae 5: 229-240.

Santos, P.C., Lopes, L., Freitas, J.S., Sousa, L.B., Carvalho, A.J.C. 2011 . Crescimento inicial e teor nutricional do maracujazeiro amarelo submetido à adubação com diferentes fontes nitrogenadas. Revista Brasileira de Fruticultura v. esp: 722-728.

Schlemmera, M., Gitelson, A., Schepers, J., Ferguson, R., Peng, Y., Shanahan, J., Rundquist, D. 2013. Remote estimation of nitrogen and chlorophyll contents in maize at leaf and canopy levels. International Journal of Applied Earth Observation and Geoinformation 25: 47-54.

Silva Júnior, G.B., Cavalcante, Í.H.L., Albano, F.G.; Osajima, J.A. 2013. Estado nutricional e clorofila foliar do maracujazeiro-amarelo em função de biofertilizantes, calagem e adubação com N e K. Revista de Ciências Agrárias 36: 163-173.

Venâncio, J.B., Rodrigues, E.T., Silveira, M.V., Araújo, W.F., Chagas, E.A., Castro, A.M. 2013. Produção, qualidade dos frutos e teores de nitrogênio foliar em maracujazeiro-amarelo sob adubação nitrogenada. Revista Científica $41: 11-20$. 